\title{
Olympic social responsibility: a challenge for the future
}

\section{Emmanuel Bayle}

To cite this article: Emmanuel Bayle (2015): Olympic social responsibility: a challenge for the future, Sport in Society, DOI: 10.1080/17430437.2015.1108646

To link to this article: http://dx.doi.org/10.1080/17430437.2015.1108646

曲 Published online: 26 Nov 2015.

Submit your article to this journal ¿

Q View related articles $₫$

View Crossmark data ¿ 


\title{
Olympic social responsibility: a challenge for the future
}

\author{
Emmanuel Bayle \\ Sports Sciences Institute (ISSUL), University of Lausanne UNIL, Lausanne, Switzerland
}

\begin{abstract}
Social responsibility, especially in the fields of education, society and peace, is one of the cornerstones of the olympic ideal and strategic vision (contribute to building a better world through sport). The article reviews the literature on organizational social responsibility (OSR) and the relationship between sport/olympism and OSR in order to examine the conditions governing the implementation and success of the International Olympic Committee's strategic vision. Several ways in which the IOC could promote a more ambitious and better-integrated social strategy: revise its performance model, notably evaluate and present in a social responsibility report; promote the adoption of OSR initiatives and strategies within the Olympic System from the bottom-up, rather than from the top-down; share best practices in the different countries for promoting and developing "sport for all"; create a World Agency for Development through Sport, or partnering and funding the international platform on sport and development; creating a World Agency for the International Governance of Sport. Two possible scenarios for the future of Olympic responsibility are finally discussed: strategy of "small steps" and a more ambitious local and global social strategy through sport and olympism.
\end{abstract}

Social responsibility, especially in the fields of education, society and peace (Chappelet 2009), ${ }^{1}$ is one of the cornerstones of the Olympic ideal. In fact, the Olympic Movement's clearly stated goal is 'to contribute to building a peaceful and better world by educating youth through sport practised without discrimination of any kind and in the Olympic spirit, which requires mutual understanding with a spirit of friendship, solidarity and fair play' (preamble of Olympic charter 2014). Given this unequivocal declaration, it would seem justified to submit the Olympic Movement's performance in the field of social responsibility to the same scrutiny that has been applied to corporate social responsibility (CSR) over the last 20 years. Because 'being responsible means giving others the right to hold you to account' (Bessire 2005), the present article examines to whom and how the IOC and the Olympic Movement are accountable.

According to the IOC's strategic vision, responsibility to society is at the heart of the Olympic project and is its explicit raison d'être. In the new version of the IOC's vision 
Olympic Movement

Vision

\section{Olympic Movement \\ Mission}

Olympic Movement Values

Working

Principles

\section{Contribute to building a better world through sport}

- Ensure the uniqueness and the regular celebration of the Olympic Games

- Put athletes at the heart of the Olympic Movement

- Promote sport and the Olympic values in society, with a focus on young people

Excellence

Friendship

Respect

Universality

\& Solidarity
Autonomy

\& Good

Governance

Figure 1. The IOC's strategic vision and mission.

Source: IOC report 2014.

statement proposed in 2014 (Figure 1), the term social responsibility has been removed from its working principles and replace with 'sustainability' because 'in the end, social responsibility applies to all our activities' (source: IOC staff interview).

The first above vision statement has been drawn up during Jacques Rogge's presidency, and have highlighted three new values in 2007 - excellence, respect and friendship - which implicitly replace the Olympic Movement's traditional motto of 'citius, altius, fortius' (faster, higher, stronger), which was considered to suggest too strongly the idea of sporting performance and never-ending growth. Following Thomas Bach's election as IOC president, this mission statement has once again been revised in order to focus clearly on athletes and young people (IOC report 2014).

The present article reviews the literature on organizational social responsibility and the relationship between sport/Olympism and CSR in order to examine the conditions governing the implementation and success of this vision. The literature search included documents relating to social responsibility and sustainable development (a term frequently used in the field of sport and by public sector, associative and non-profit organizations outside the corporate world) produced by the IOC, international sport federations (IF), other stakeholders in the Olympic Movement (NOCs, OCOGs, etc.), Olympic partners and sponsors, national governments and the European Union. Additional data were provided by five semi-structured interviews with experts in the field ( 3 people at the IOC, 1 person at SportAccord, 1 outside expert), covering representations of Olympic social responsibility (OSR), how the IOC can manage OSR internally and across the Olympic Movement in general, the value and limitations of managing OSR and ways of measuring and reporting performance in this area. 
A review of the context and stakes surrounding OSR is followed by an assessment of the IOC's responsible/sustainable sport advocacy strategy, while the final section looks at how the IOC and the Olympic Movement could move towards a more ambitious and more integrated social strategy.

\section{Context and stakes}

For Gond and Igalens (2010), Corporate Social Responsibility, a term originally coined by Bowen (1953), has gradually become an important issue on corporations' agendas. By the 1990s, the notion had been embraced by most other types of organization, thereby introducing a new paradigm that has changed the boundary between 'for-profit' and 'nonprofit' bodies. Hence, the issue of OSR has to be examined within this context of evolving representations and modes of managerial action.

\subsection{From CSR to OSR: a promise of responsible entrepreneurship}

CSR has been defined as: 'voluntary contributions by companies in order to meet their economic, legal, ethical and philanthropic responsibilities to their stakeholders' (European Commission 2001). A profusion of CSR standards and labels have been issued since sustainable development rose to prominence on the political agenda in the early 1990s. They include:

- The OECD's guidelines for responsible business conduct (first published in 1976; 5th edition in 2011).

- The Global Reporting Initiative (GRI, 1997) - sustainability reporting guidelines (G4 since 2013).

- The United Nations Global Compact, published in 2000, which lays down 10 principles in four areas of CSR.

- The principles for responsible investment drawn up by the United Nations Environment Program Finance Initiative (UNEP FI) in 2005.

- The 2001 European green paper on CSR.

- ISO standards (especially 14000/8000 for environmental management systems and the ISO 14001/ISO 14004/ISO 14010/ISO 14012 individual standards).

- Numerous fair trade labels.

In addition to these international incentives, some countries have imposed social reporting obligations on companies above a certain size. In France, for example, such obligations are included in article 116 of the 2001 New Economic Regulations Act and article 225 of the 2012 'Grenelle 2' Environment Summit.

These new rules have prompted the introduction of new governance, management and performance measurement methods among (large) companies and resulted in the emergence of firm social strategies, the concept of shared value (Porter and Kramer 2011; applied, for example, by Nestlé - 'Value for Nestlé \& Value for Society'), measures of social performance (Gond and Igalens 2010) and the associated issues of corporate social reporting (Sautereau-Moquet 2010) and non-financial ratings. The notion of global corporate performance, developed over the last three decades from earlier models of corporate social performance (Carroll 1979; Wartick and Cochran 1985) and first defined by Wood (1991), 
extends the measure of corporate performance beyond simple financial criteria. This notion is symbolized by the concept of the triple bottom line (Elkington 1997), that is, the need for corporations to measure their social and environmental performance, as well as their economic performance. The notion of global performance has now spread to other types of organization outside the corporate world (public bodies, associations, etc.), partly due to the emergence of new international standards specifically addressing the Social Responsibility of Organizations (SRO) (Gond, Travaillé and Bayle 2014). Perhaps, the most important of these standards is ISO 26000 (2010), a non-certification standard that defines social responsibility as 'an organization's contribution to sustainable development which takes the form of a willingness by the organization to accept responsibility for the impacts of its decisions and activities on society and on the environment and to report these impacts'.

This new paradigm is supposed to lead to the reconfiguration of management processes ( $R \& D$, purchasing, human resources, logistics, marketing and social communication, corporate foundations, carbon footprint, triple bottom line and social or 'non-financial' ratings, etc.) in every organization, large or small. It has also given rise to new forms of business, such as green enterprises (Chambolle 2007), social businesses, sometimes based on micro credit (Yunus 2010), and 'bottom of the pyramid'2 (BoP) strategies (Prahalad 2004; Martinet and Payaud 2008, 2010) for creating economic models adapted to the needs of the poorest people in developing countries. Some large corporations have revised their management models (e.g. Danone's 'Danone Way', Gond and Igalens 2012) and financed new economic models (e.g. the famous 'Grameen-Danone' joint venture in Bangladesh, Yunus 2010; Gond and Igalens 2012). These new management conventions have the power to transform capitalism, but they can also be used as arguments to legitimize and improve the reputation of neo-capitalism. Consequently, they must be subject to critical examination in order to ensure they are not just examples of 'greenwashing' (Friestad and Wright 1994).

The need to measure social impacts has also affected public organizations working towards the UN's Millennium Development Objectives (MDO, 2000-2015), which have now been transformed into sustainable development objectives for the period up to 2030 . In the case of public bodies, the issue of sustainable development has had a much bigger impact than social responsibility with respect to the adoption of new management tools such as national sustainable development strategies, sustainable city policies, local Agenda 21s and environmental protection standards. This paradigm has also led to reflections on alternative ways of assessing a country's success rather than through the traditional measure of GDP (e.g. the Bhutan government's 'Gross National Happiness' concept, 1972; report of the Stiglitz Commission 2009; Cohen 2012, etc.).

Although these changes have modified representations of corporate governance, management and evaluation, it would be naïve to think they have led to a real transformation in financial capitalism (Boltanski and Chiapello 1999).

\subsection{The paradox of the apparent convergence of organizations}

Despite its limitations, the new focus on CSR is further evidence that multinationals and their constituent companies have moved away from a uniquely market-oriented outlook and have 'entered society' (Martinet and Payaud 2008). In other words, corporations now have to think about managing their actions' consequences on society. The roots of this idea are very old, extending back to utopian factories, corporate paternalism, the Protestant 
Table 1. CSR principles applied to the Olympic Movement and multinationals.

\begin{tabular}{|c|c|c|}
\hline CSR Principles & Olympic Movement & Multinationals \\
\hline CSR 'MODEL' & DNA Advocacy & Business/Responsible management \\
\hline Purpose & Societal & Profit and value creation (shared) \\
\hline CSR Strategy & $\begin{array}{l}\text { Legitimizing business to serve a } \\
\text { social/societal project }\end{array}$ & Societal - Legitimizing profit \\
\hline CSR Regulation & $\begin{array}{l}\text { Ethical regulation/communication } \\
\text { - Events }\end{array}$ & $\begin{array}{l}\text { Responsible value chain/Communi- } \\
\text { cation }\end{array}$ \\
\hline Stance with Respect to CSR & Reactive & Proactive \\
\hline Impacts on the Economic Model & Weak - responsible partnerships & $\begin{array}{l}\text { New economic model + 'Bottom of } \\
\text { the pyramid' }\end{array}$ \\
\hline Performance/Accountability & $\begin{array}{l}\text { Report championing actions/ } \\
\text { communication }\end{array}$ & New principles and tools \\
\hline
\end{tabular}

capitalist ethic, business ethics and the stakeholder approach to strategy. At the same time, many large international sports associations, such as the IOC, have definitively entered the commercial marketplace by starting and/or growing businesses, many of which are quite large, while, in some cases, forgetting their original values and social objectives.

This gives rise to the paradox of corporations increasingly referring to themselves as civic or social, while NGOs and large associations are being defined by the courts as 'de facto commercial enterprises' and considered by the public as 'money-making machines. The result is a blurring of the historic boundaries between the mercantile and non-mercantile, for-profit and non-profit, the general and individual interests and public and private sectors, etc.

Moreover, there is great inequality in the facility with which sustainable development and SRO can be implemented, as sports' international governing bodies tend to be at the head of loosely-knit and disparate networks of continental and national associations, whereas multinationals are professional, well-organized structures that tightly control their subsidiaries and subcontractors. In addition, even the largest sports associations are no bigger than medium-sized companies and rarely have more than 500 staff at their international headquarters (e.g. IOC, FIFA, UEFA), while multinationals often have several thousand employees.

Nevertheless, there is a basic difference in the way CSR is applied by associations and corporations, as it is an objective for the former and a means to an end for the latter (Table 1).

The increased prominence of SRO on the political agenda and the apparent blurring of boundaries between different types of organization raise the question of whether the IOC goes about achieving its stated objectives in a truly socially responsible way (see Figure 1).

\subsection{Is Olympism (the IOC) socially responsible?}

The IOC and the Olympic Movement hold a monopoly on a worldwide 'public good' known as Olympism, which critical sociologists have long referred to as the new 'opium of the people' (Brohm 1976). However, there are still no real international checks and balances on the governance of the IOC or the IFs within an Olympic System that now includes numerous stakeholders (see the article by J.-L. Chappelet in this issue). Given the growing financial importance of the Olympic phenomenon and the Olympic Games, improper conduct, including poor governance, corruption, worship of mammon, doping and the use of sport to further geopolitical or economic aims, has the potential to severely damage the reputations of the IOC and organizations belonging to the Olympic System. 
This has led to greater transparency, although, rather than coming from IOC members, athletes and sponsors, pressure to become more transparent has come mostly from other sources, including public opinion, NGOs (Amnesty International, Transparency International, WWF etc.), investigative media (especially in English-speaking countries), social networks and some national governments, notably Switzerland, which is home to most of the world's largest sporting bodies. On 12 December 2014, Switzerland's parliament passed the 'Lex FIFA' Act, which is designed to combat money laundering by allowing Swiss prosecutors to investigate the heads of sports institutions and their entourages. However, it is the United States justice system that has laid bare the largest scandals, including the corruption surrounding Salt Lake City's bid for the 2002 Winter Olympics, FIFAgate and doping (Balco and Armstrong affairs). These investigations resulted in major reforms in world sport, including the creation of the World Anti-Doping Agency in 1999 and reform of the IOC in 2000 (Chappelet 2001, 2002).

Scandals within sports administration offend more than just the business world because the IOC's message of Olympic values mean that it is expected to meet exemplary standards. The IOC vaunts the success of its business and its apparently generous redistribution model ( $90 \%$ of revenues distributed to other members of the Olympic System), but the results and impacts of its actions are often unclear and difficult to measure.

The increased focus on social responsibility and its associated risks raise the question of the scope of OSR. The IOC and the Olympic Movement it manages are pursuing an ambitious social project with authority and claims of exemplarity, but fundamental questions remain unanswered:

- What role does the IOC, and the Olympic and sporting movements in general, want to play in society?

- How can Olympism's contribution in the social, economic and environmental fields be improved and measured?

- Does social responsibility concern only the IOC, or does it also concern the IOC group (its commercial subsidiaries and foundations) and OCOGs, which are, according to people inside the IOC, 'under its control' (source: interview). Does it concern the wider Olympic System, made up of NOCs and IFs, over which the IOC admits it has only 'a power of influence' (source: interview). Or does it concern the 'total Olympic system' (Chappelet, in this issue), which could be considered a case of extended influence.

Answering these questions is essential in order to determine where the IOC's social responsibility starts and finishes, especially with respect to the legal and political autonomy of the NOCs and IFs. Although the IOC can exert considerable pressure on NOCs and IFs, because of its control over the redistribution of Olympic revenues and its power to decide who can and who cannot participate in the Olympics, it is not a multinational corporation that can impose its choices and control its subsidiaries. In addition, the IOC rarely uses its power to dictate changes in governance and management (recent exceptions include exerting pressure on SportAccord in order to obtain its president's resignation and then the dissolution of the association, ${ }^{3}$ and suspending India's, Kuwait's and Afghanistan's NOCs).

Thus, SRO would appear to promise a new, some would say utopian, approach to governance and to managing and evaluating organizations, that is, a way that is more responsible and more sustainable. In this light, the following section shows that the IOC's strategy could be considered a form of advocacy for responsible/sustainable sport. 


\section{Advocacy for responsible/sustainable sport}

This section divides the history of what can be called 'responsibility advocacy' into three periods and then examines the current state of OSR and the semantic and organizational changes it is eliciting within the IOC.

\subsection{The three periods of OSR}

Three distinct periods can be recognized in the Olympic Movement's approach to social responsibility: Coubertin's vision of Olympism; Samaranch's liberal and capitalist 'revolution'; and, most recently, the search for a new type of OSR strategy that began when Thomas Bach took over the IOC's reins.

The first period dates back to the formulation of Olympic ethics and values, based on Coubertin's doctrine and its elitist, liberal, pacifist and educational DNA (Clastres 2004). This period was followed by the 'Samaranch revolution' in which Coubertin's original ideals were updated in the context of 1980s globalized financial liberalism and capitalism, and the end of the cold war following the break-up of the Eastern bloc in the early 1990s. The final decade of the twentieth century was also marked by the Bruntland report (1997) and the Rio summit (1992), which put sustainable development at the heart of the world's political agenda. As early as 1994, the IOC had used sustainable development to reinforce its legitimacy by making the environment the third dimension of Olympism, alongside sport and culture. This was followed by the creation of the Sport and Environment Commission in 1995 and the publication of Agenda 21 'Sport for sustainable development' in 1999. The Olympic Games, especially the Winter Games from Lillehammer onwards (Chappelet 2008), felt the need to be ever greener and ever more virtuous in this domain. More generally, the 1990s saw the IOC develop its partnerships with UN organizations, with diplomatic efforts begun under Samaranch bearing their greatest fruit in 2009, when the United Nations General Assembly granted the IOC observer status. However, other events during this period severely tarnished the IOC's and Olympic Movement's reputation, leading to the creation of new regulatory bodies (Court of Arbitration for Sport, 1984, World Anti-Doping Agency, 1999) and new efforts to introduce 'good governance' (IOC 2000). In 2008, the IOC drew up its 'Basic Universal Principles of Good Governance of the Olympic and Sports Movement', but the NOCs and IFs have paid little heed to its recommendations (Chappelet 2015).

In the final year of Jacques Rogge's presidency, the IOC published two important documents relating to sustainability and social responsibility:

- $R I O+20$ : 'Sustainability through sport: Implementing the Olympic Movement's Agenda 21' (IOC, 2012), which was essentially a list of sustainable development actions carried out by the IOC and during the Olympic Games;

- ISO 20121 (2012): 'Event Sustainability Management Systems - Requirements with guidance for use', presented as a legacy of the London Olympics in terms of sustainable development.

Sustainable development was also the theme of a 2012 forum organized by the IFs: 'Increasing the positive impact of your event: Sustainable Event Management', which showed that the international sports movement had accepted the need for more responsible events management. Nevertheless, very few IFs adopted comprehensive strategies addressing social 
issues or truly committed themselves to development through sport (source: interview SportAccord).

Thomas Bach's election as IOC president, in 2013, appears to have heralded the beginning of a third period characterized by doctrinal questions about the challenges posed by a global and integrated social responsibility strategy concretized by the signature of an agreement in April 2014 with United Nations to reinforce the collaboration between the two institutions (IOC report 2014). Symbol of this reinforced partnership; the 6 April 2014 marked the first worldwide celebration of the International Day of Sport for Development and Peace, established by a resolution of the United Nations General Assembly.

In fact, this type of integrated approach of CSR has already been pioneered by some large commercial sports organizations, such as the NBA, whose strategies involve leagues, franchises, players and partners. The result is one of the sporting world's very few formalized and integrated CSR strategies (Sheth and Babiak 2010; François and et Bayle 2011).

\subsection{An attempt to depict current OSR: a rich but splintered approach}

Figure 2 shows that the Olympic Games remains the IOC's flagship, due to massive public investment and a sometimes strong approach to sustainable development promoted by each

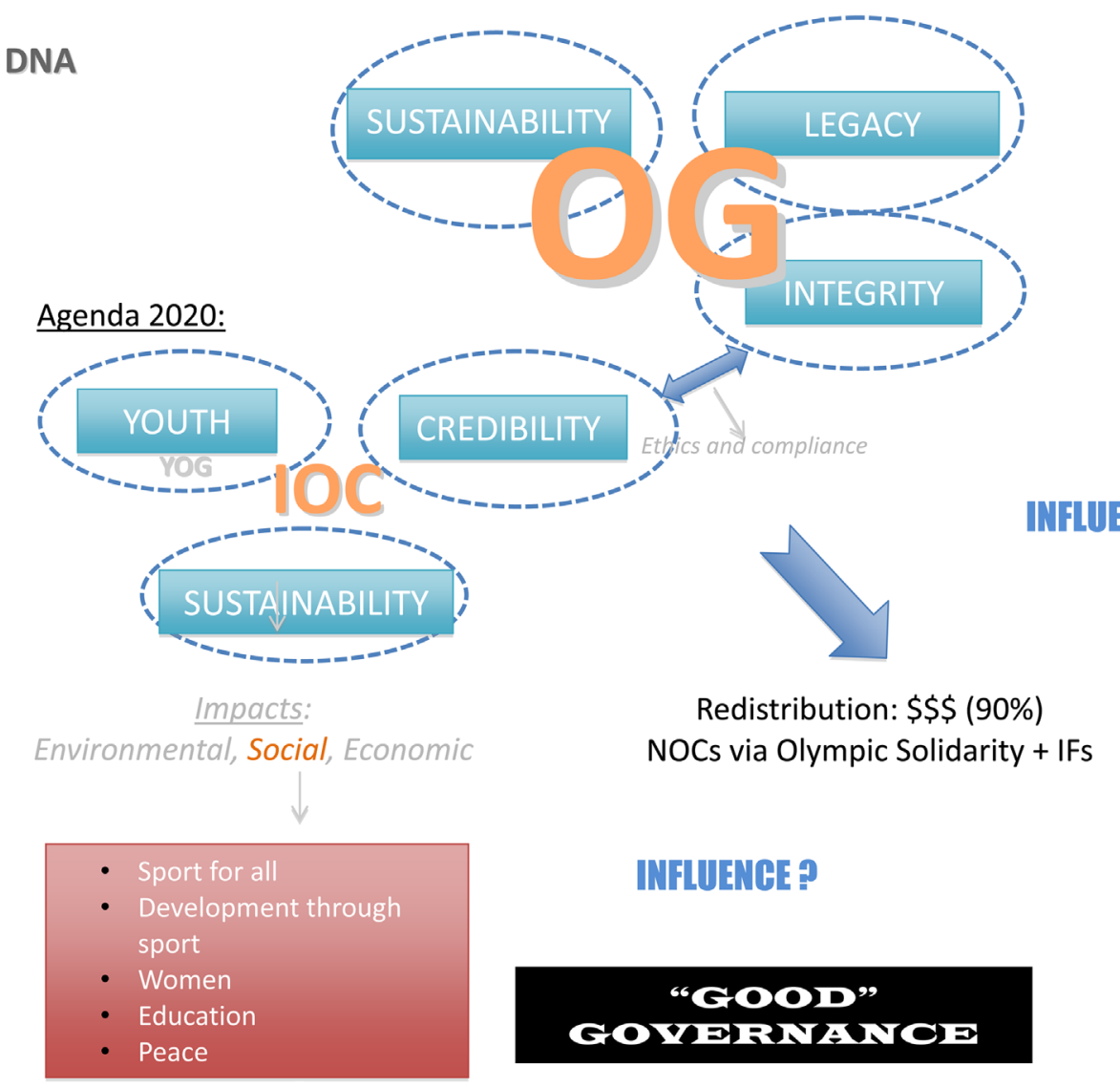

Figure 2. The author's attempt to depict OSR in 2015. 
OCOG's public partners. Effectively Olympic Games generate, in parallel more and more programmes: on sport practice, public heath, sustainable development, social integration, cultural initiatives (...). Nevertheless, the extent of an OCOG's sustainable development actions depends on the host country (Beijing/London; Vancouver/Sochi), and the impact and legacy of the Olympics in the host country have proved difficult to measure despite attempts to assess the longer term impacts of the Games (OGI $\left.{ }^{4}\right)$. The IOC's new OSR policy for the Games is based around three key concepts: sustainability, legacy and integrity. Integrity involves protecting sport from inappropriate behaviours that have previously tarnished the image of the Olympics (doping, match fixing, etc.). In addition, the IOC has structured its internal OSR policy around three concepts: sustainability, youth and credibility. However, despite obvious changes in young people's behaviours (less interest in the Olympics and in competitive and club-based sport, less active lifestyles that are starting to impact health and life expectancy), ${ }^{5}$ it could be said that the IOC is yet to adopt a true youth strategy, as its current strategy is based mostly on the Youth Olympic Games with programmes like 'youth empowerment', which concern only a very small population of young elite athletes. The issue of sustainability is approached in terms of the IOC's social, economic and environmental impacts. On the social level, the IOC has announced five major orientations - Sport for all, Development through Sport, Women and sport, Education and Peace through sport - although this is more a declaration of intent than a structured and coercive policy with a clear plan of actions. The question of 'good governance' has been one of the IOC's greatest preoccupations since the early 2000s (Chappelet 2013, 2015; Chappelet and Mrkonjic 2013) has led to efforts to act more responsibly. However, these efforts seem to have had little influence on other organizations within the Olympic Movement (NOCs, IFs and NFs), thereby leaving the Movement exposed to the risks noted above.

Figure 2 is the author's personal attempt to depict OSR, based on analyses of documents and websites, together with interviews with senior IOC administrators. It is an attempt to provide a coherent picture of OSR, which is far from being well known and shared by the IOC's members, managers and directors. However, it is not very clear how the social strategy shown in Figure 2 is implemented and, most importantly, there is no alignment between the IOC's organizational structure and its social strategy.

In fact, the different components of OSR shown in Figure 2 are managed in a much dispersed way, involving several different directorates and commissions. This clearly shows the limitation of the 'silos approach'. Furthermore, the network of NOCs is very heterogeneous (autonomous and loosely-knit), with 'only around 20 NOCs out of 205 truly addressing these issues' (source: interview), and the IFs are 'poorly organized, non-professional and little interested in the issue of social responsibility; this question is mostly engaged via "sport development" and especially during the attribution of major events, even if they do not organize them themselves' (source: interview).

Although the IOC boasts of international partnerships and worldwide initiatives as part of its social strategy (UN, NGOs, multinationals, etc.), these agreements are not very active around the globe and remain very 'cosmetic' (source: interview). This is why the IOC would like to do better, but with limited human and financial resources, as is shown by the semantic and organizational restructurings currently being carried out at the IOC's headquarters. 


\subsection{Ongoing semantic and organizational restructurings within the IOC}

In 2015, the IOC's International Relations Commission was renamed the Public Affairs and Social Development Through Sport Commission and had sustainability added to its institutional and brand development missions. The IOC has also appointed a Chief Ethics and Compliance Officer and renamed the Sport and Environment Commission the Sustainability and Legacy Commission. A new Olympic Games candidature invitation phase has been introduced to encourage more cities to bid to host the Games and to allow the IOC to 'plan ahead for the organization of the Olympics in order to ensure potential benefits are managed responsibly, both within and outside the host country' (source: IOC interview). Finally, the IOC's social objectives, its volunteer-based operations and its selflessness are symbolically highlighted by the signature added to all emails sent by IOC staff since 2014:

The International Olympic Committee is a not-for-profit independent international organization made up of volunteers, which is committed to building a better world through sport. It redistributes more than 90 per cent of its income to the wider sporting movement, helping athletes and sports organizations at all levels around the world.

In summary, it can be said that the DNA and raison dêtre of Olympism includes the desire to improve society through its actions, while focusing mostly on elite Olympic sport. The IOC has not put much pressure on other members of the Olympic Movement, most notably the NOCs and IFs, to improve their efforts in the field of sustainable development and OSR, despite providing them with ever-larger sums of money. This distribution of resources could be seen as being designed to maintain the political and economic balance within the Olympic System and to protect the System's economic model, which has been weakened by the shortage of candidates to host the Olympics (see the articles by John MacAloon and Jean-Loup Chappelet in this issue).

Actions with respect to sustainable development and OSR remain splintered. The IOC has no global integrated policy and only a weak ability to bring either the NOCs or IFs into line. This is also the case for athletes, who have, however, launched numerous individual initiatives, mostly involving their foundations and charitable and civic actions.

Nevertheless, in the eyes of public opinion, the Olympic Movement still has the power to use sport to create a positive impact on the economic, educational, health and environmental challenges facing the world. So what could the IOC do in terms of producing a stronger and more integrated social strategy?

\section{Towards an Olympic social strategy}

Despite being seen as a rich and prosperous organization, the IOC has few resources for taking direct worldwide action to develop grassroots sport or promote development through sport. However, through its levers (Olympic Games, Olympic recognition, its five-ring logo which is 'the most widely recognised of all the brand symbols surveyed' - IOC report 1994), it is able to exert a lot of influence and pressure on other members of the Olympic System and on society in general. Hence, there are several ways in which the IOC could promote a more ambitious and better-integrated social strategy.

First, the IOC should revise its performance model, that is, the way it evaluates its success and that of the Olympic Movement, by making societal performance the central measure of performance. Sports organizations that have done this include the French Football 
Federation, which, through its foundation, has tried to produce a global overview of football's social impact (Bayle 2014), and the Italian Motorcycle Federation, which has published a social report. The IOC could take up such ideas and tools, which have emerged since 2010, and promote and facilitate their adoption within the Olympic Movement. Hence, the IOC must first decide which areas of society to target, which indicators to use to assess success, which reporting systems to use and how to ensure accountability.

An additional stage in evaluating organizations within the Olympic Movement (NOCs, IFs, NFs) would be to insist that they publish, in addition to their annual report, a social responsibility report, as is required of large corporations in many western countries. This report would provide an assessment of their social performance (see Capron and Leseul 1997; Capron 2003), perhaps measured following the guidelines provided by ISO 26000.

A second idea would be to promote the adoption of OSR initiatives and strategies within the Olympic System from the bottom-up, rather than from the top-down. Chappelet (2009) suggested introducing an 'OSR hub for the Olympic System'. It may be possible to group together all OSR steering tools in an ISO 26000 Sport CSR, as has been done by La Française des Jeux and France's NOC (CNOSF). Such an approach would allow the sharing of feedback from experiments undertaken by the most advanced Olympic organizations.

Another way in which OSR can move beyond the Olympic elite is to share best practices for promoting and developing 'sport for all' (in partnership with UNESCO and the CIGEPS) and to ensure physical and sports activities are integrated into public policies in fields outside education, such as health, social integration, employment, tourism and other fields that will vary from country to country. An international learning community could be formed to share best practices, which are essential to strengthening a country's sporting culture.

In order to raise new finance and bring together initiatives around the concept of development through sport, the IOC could help create a World Agency for Development Through Sport, thereby using sport as an explicit instrument of development. In this respect, and to facilitate the creation of such an agency, Olympic sports organizations (IOC, NOCs, IFs and NFs) could work together or call upon specialist development organizations to create specific bodies to carry out sport-based actions, especially in developing countries (at the example of Olympafrica).

Such bodies could take the form of national agencies for development through sport, sport-based social enterprises financed by micro-credit, international development funds and corporate and individual foundations. Progressively, finance could also be channelled to a 'BOP Olympic' strategy to develop grassroots sport among the poorest segments of society.

Another less ambitious project but may be more realistic to partnering and funding the international platform on sport and development (http://www.sportanddev.org/fr/) and other big NGOs we use sport as a tool for development. Indeed, 'the IOC does not have an international expertise in the field on development through sport that's why it could be a slippery slope for IOC and Olympic movement' (source: interview).

Governance is the first of the seven domains of the ISO 26000 standard. In order to effectively implement OSR, all of the organization's main directors must accept the need for good governance. This is why I would suggest creating a World Agency for the International Governance of Sport, along similar lines to the World Anti-Doping Agency (Chappelet 2002), in order to ensure that governance is OSR-oriented and to check that organizations 
within the Olympic Movement follow the principles of 'good' governance. By evaluating the degree to which Olympic organizations comply with the principles of good governance, this agency could supply the IOC with data that could then be used to decide whether or not an organization should be allowed to use the Olympic label and determine the proportion of Olympic revenues it should receive. Olympic organizations would also be expected to adopt OSR-oriented strategies, with help being provided to those organizations and/or countries that need it. The goal would be to impact the three levels of governance described by Henry and Lee (2004):

- Organizational: that is, the functioning of the board and its relations with directors,

- Political: relations with public bodies, often through conventions or performance contracts,

- Systemic: that is, working with all stakeholders in order to create the conditions needed for collaborative governance (Shilbury and Ferkins 2015).

\section{Conclusion}

In the 120 years since the revival of the Olympic Games, the Olympic project has based its legitimacy on a succession of guiding principles: Olympic values/ethics and Coubertin's vision for the Olympics were followed by sustainable development, which has itself been succeeded by OSR. As a result, and despite a number of crises, Olympism has developed a powerful but fragile image. Throughout its existence, the IOC has relied on public relations as its main tool for legitimizing Olympic actions.

Contrary to the corporate world, the IOC has done little to question how it creates, measures and reports (social) value of his activities. ${ }^{6}$ The concept of OSR provides the Olympic Movement with a new of way underlining its legitimacy; however, it also raises new challenges for the governance and management of the Olympic System. Although the Olympic and sports movements do not necessarily have the means to implement global OSR strategies, they could call upon the expertise and resources provided by new stakeholders in the Olympic System, for example, ministries of education, health, foreign affairs and finance, foundations, NGOS, new social businesses and the social economy sector. By doing so, they would be able to obtain the resources needed to use sport's potential to alleviate numerous societal problems in fields such as education, health, social ties, exclusion, unemployment, sustainable development, tourism and regional identity.

There appear to be two possible scenarios for the future of Olympic responsibility:

(1) Maintain the current status quo by making small adjustments to strategy ('small steps') in order to develop OSR and relying on 'influence' to instigate changes across the Olympic System, while accepting compromises and avoiding a profound reassessment of the IOC's actions.

(2) Commit to a strong local and global social strategy by using sport and Olympism to promote and encourage social innovations and thereby build a 'better world'. Create a new utopia in order to use sport to help bring about economic, demographic, religious and geopolitical change in a multipolar and increasingly complex world.

Given the history of the IOC and its recently presented Agenda 2020, it would seem most likely that it will opt for the former, more prudent and more conservative scenario. 


\section{Notes}

1. http://www.olympic.org/Documents/Olympic_Museum/Education/DPHOPE/DP_Hope_ FR_web.pdf ('When sport can change the world - Olympic Museum educational kit').

2. In economics, the bottom of the pyramid is the largest, but poorest socio-economic group, consisting of the three billion people who live on less than US $\$ 2.50$ per day.

3. http://www.sportaccord.com/upload/ResignationletterFR.pdf.

4. 'Standardized data for 126 environmental, sociocultural and economic indicators are to be collected. The IOC's Technical Manual on OGI describes the purpose and scope of each indicator as well as its recommended calculation methods and measurement procedures. These 126 sustainability indicators comprise 80 indicators that assess the context within which the Games are being held, and 46 indicators geared to provide assessment of the Olympic event itself. Depending on the indicators' characteristics, data are requested for different geographic scales, ranging from the municipal level to the national level. The OGI study covers a period of twelve years and involves a series of four reports. The first is a Baseline Report which provides contextual data to serve as a baseline for the subsequent reports, and it is focused on the indicators data for the reference year (i.e. two years prior to the host city election; 2001 for VANOC, the Vancouver Organizing Committee for the 2010 Olympic and Paralympic Winter Games). The Baseline Report is followed by a Pre-Games Report, which analyzes updated contextual data. Next, a Games-Time Report (to examine Olympic-event data) and a Post-Games Report (to assess updated data, summarize findings from previous reports, and provide final conclusion about the impact of the Olympic Games) conclude the OGI Study'. http://css.ubc.ca/projects/olympic-games-impact-study/about-ogi/

5. https://www.designedtomove.org/.

6. Value chain: sequence of activities or actors which supply products or services to an organization (supply chain) viewed in terms of its real impact on cost and quality, and which gives an organization a competitive advantage.

\section{Disclosure statement}

No potential conflict of interest was reported by the author.

\section{References}

Bayle, E. 2014. "Évaluation de la réussite des fédérations sportives: vers une performance sociétale? [Evaluation of success of sport federations: towards a societal performance? in Management and evaluation of organisational performance: a challenge for sport organisations] " In Management et évaluation de la performance, un défi pour les organisations sportives. Coll. Management \& Sport, edited by M. Winand and T. et Zintz, 57-66. Brussels: De Boeck.

Bessire, D. 2005. Responsabilité sociale de l'entreprise et parties prenantes : compter ou discuter? Comptabilté et Connaissances, Mai. https://halshs.archives-ouvertes.fr/halshs-00581129/document.

Boltanski, L., and E. Chiapello. 1999. Le nouvel esprit du capitalisme. éd [The new spirit of capitalism]. Paris: Gallimard.

Bowen, H. R. 1953. Social Responsibilities of the Businessman. New York, NY: Harper \& Brothers..

Brohm, J.-M. 1976. Sociologie politique du sport [Political sociology of sport], réédition: Nancy, P.U.N., 1992, 398.

Carroll, A. B. 1979. "A Three-Dimensional Model of Corporate Performance." Academy of Management Review 4 (4): 497-505.

Capron, M., \& Leseul, G. 1997. "Pour un bilan sociétal, Revue des études coopératives mutualistes et associatives [For a societal balance sheet]." RECMA no $26628-41$.

Capron, M. 2003. "Une nouvelle démarche dévaluation des organisations: le bilan sociétal, Comptabilité, Contrôle [A new way of organization's evaluation : societal balance sheet]." Audit, mai 55-69. 
Chambolle, T. 2007. Les éco-entreprises, Les annales des mines; Réalités industrielles, novembre. http:// www.annales.org/ri/2007/ri-novembre-2007.html.

Chappelet, J.-L. 2001. "Le Système olympique et les pouvoirs publics face au dopage et à la corruption: partenariat ou confrontation? [The olympic system and the public authorities facing doping and corruption: partnership or confrontation? In Sport and public order]" In Sport et ordre public, sous la direction de J.-Ch. Basson, 215-234. Paris: La documentation française, collection « IHESI - La sécurité aujourd'hui ».

Chappelet, J.-L. 2002. "L'Agence mondiale antidopage, un nouveau régulateur des relations internationales sportives [World Anti-Doping Agency, a new regulator of sport international relationships].” Relations Internationales (111, automne): 381-401.

Chappelet, J.-L. 2008. "Olympic Environmental Concerns as a Legacy of the Winter Games." The International Journal of the History of Sport 25 (14): 1884-1902.

Chappelet, J.-L. 2009. "Corporate Social Responsibility: A New Frontier for the International Olympic Committee." In Social Responsibility and Sustainability in Sports, edited by P. Rodríguez, S. Késenne, and H. Dietl, 17-29. Oviedo: Universidad de Oviedo.

Chappelet, J.-L. 2013. “The Global Governance of Sport: An Overview." In Routledge Handbook of Sport Policy, edited by I. Henry and L.-M. Ko, 63-74. New York: Routledge.

Chappelet, J.-L. 2015. "Autonomy and Governance: Necessary Bedfellows in the Fight against Corruption in Sport." In Global Corruption Report 2015: Sport, edited by Transparency International.

Chappelet, J.-L., and M. Mrkonjic. 2013. Basic Indicators for Better Governance in International Sport (BIBGIS): An Assessment Tool for International Sport Governing Bodies. Working paper de l'IDHEAP, IDHEAP, (1/2013), 54.

Charte olympique. 2014. Charte olympique, état en vigueur au 8 décembre 2014 [Olympic Charter, current version]. Lausanne: CIO.

Clastres, P. 2004. Comment Coubertin réinvente l’olympisme? Les Cahiers de Science et Vie, $\mathrm{n}^{\circ}$ spécial Lépopée des jeux olympiques, juillet, July: 104-107.

Cohen, D. 2012. Homo economicus. Prophète (égaré) des temps nouveaux [Hono economicus. Lost prophet in new times], edited by A. Michel. Paris: A. Michel.

Elkington, J. 1997. Cannibals with Forks. The Triple Bottom Lines of the 21st Century Business. Oxford: Capstone.

François, A., and E. et Bayle. 2011. "Responsabilité sociale des organisations sportives professionnelles.” In Sport et RSE. Vers un management responsable? [Social Responsability of professional sport organisations. In Sport and CSR. Towards a responsible management?], edited by E. Bayle, J.-L. Chappelet, A. François, and L. Maltese, 81-118. Bruxelles: De Boeck Editions.

Friestad, M., and P. Wright. 1994. "The Persuasion Knowledge Model: How People Cope with Persuasion Attempts.” Journal of Consumer Research 21 (June): 1-31.

Gond, J.-P., and J. Igalens. 2010. La responsabilité sociale de lentreprise [Corporate Social Responsability]. Paris: Presses Universitaires de France.

Gond, J.-P., and J. Igalens. 2012. Manager la responsabilité sociale de l'entreprise [Managing corporate social responsability]. Paris: Pearson.

Henry, I., \& Lee, P. C. 2004. Governance and ethics in sport, in Beech \& S. Chadwick (Eds), The business of sport management, England: Prentice Hall.

IOC Annual Report. 2014. Credibility, Sustainability and Youth. www.olympic.org/Documents/ THE\%20IOC/Annual_Report/2014_IOC_AnnualReport_ENG_onscreen.pdf.

ISO. 2010. Lignes directrices relatives à la responsabilité sociétale [Guidelines for Social Responsability]. Genève: International Standardization Organization, 127.

Martinet, A. C., and M. A. Payaud. 2008. "Formes de RSE et entreprises sociales." Revue française de gestion [CSR forms and social business: an hybridation of strategies] 34 (180), Janvier-Février: 199-214.

Payaud, M., and A.-C. Martinet. 2010. "Stratégies RSE-BOP et soin des communautés humaines." Concepts et propositions génériques [CSR's strategies and care of social communities: concepts and proposals], Management International, printemps 14 (2): 31-51.

Porter, M., and D. Kramer. 2011. “Creating Shared Value." Harvard Business Review 89: 1-2. 
Prahalad, C. K. 2004. Fortune at the Bottom of the Pyramid: Eradicating Poverty through Profits. San Francisco: Wharton School Publishing.

Sautereau-Moquet, C. 2010. Le contrôle sociétal: les cas Lafarge et Danone: de nouveaux modèles de management portés par le projet de développement durable [Societal controle : Danone and Lafarge. New management models towards sustainable development]. Paris: Vuibert.

Sheth, H., and K. Babiak. 2010. "Beyond the Game: Perceptions and Practices of Corporate Social Responsibility in the Professional Sport Industry." Journal of Business Ethics 91 (3): 433-450.

Shilbury, D., and L. Ferkins. 2015. "Collaborative Governance: Mapping Future Sport Governance Research.” North American Society for Sport Management Conference (NASSM 2015), Ottawa, June 2-6, 2015, 103. www.nassm.org/files/conf_abstracts/2015-119.pdf.

Stiglitz, J., A. Sen, and J.-P Fitoussi. 2009. Rapport de la Commission sur la mesure des performances économiques et $d u$ progrès social. www.ladocumentationfrancaise.fr/var/storage/rapportspublics/094000427.pdf.

Travaille, D., J.-P. Gond, and E. Bayle. (Dir) 2014. La responsabilité sociétale des organisations: des discours aux pratiques?[Social responsibility of organizations: from speeches to practices?]. Paris: Vuibert. 340.

Wartick, S. L., and P. L. Cochran. 1985. “The Evolution of the Corporate Social Performance Model.” Academy of Management Review 10 (4): 758-769.

Wood, D. J. 1991. "Corporate Social Performance Revisited." Academy of Management Review 16 (4): 691-718.

Yunus, M. 2010. “Corporate Social Performance Revisited.” Building social business: The new kind of capitalism that serves humanity's most pressing needs New York, NY: Public Affairs. 